\title{
EMISSION CHARACTERISTICS OF A DIESEL ENGINE USING SOYABEAN OIL AND DIESEL BLENDS
}

\author{
N.A. Ansari ${ }^{1}$, Jitendra Kumar ${ }^{2}$, Amitkumar ${ }^{3}$, DhananjayTrivedi ${ }^{4}$ \\ ${ }^{1}$ Asst. Professor, ${ }^{2,3,4}$ M.Tech Scholars, Department of Mechanical Engineering, Delhi Technological University, \\ New Delhi, India, \\ mach_jeetu28575@yahoomail.com,amitkumar_ntpc@yahoo.co.in,dhan1989@gmail.com
}

\begin{abstract}
Diesel engines have been playing a vital role in the transportation and power generation sectors since from its invention. Despite of having better efficiency with diesel engine, the main concern is on emission of pollutants. There are various methods to reduce pollutant emission from a diesel engine. The prominent way to reduce pollutants is the usages of bio fuels with some modifications in the diesel engine. Diesel engine simulation models can be used to understand the combustion performance, prediction of emission concentration. These models can reduce the number of experiments. In this study, the performance and emissions characteristics of single cylinder, four stroke, and direct injection diesel engine operating on diesel and soybean blends have been investigated theoretically. The variations of various species concentration like $\mathrm{CO}_{2}, \mathrm{CO}$ and $\mathrm{NO}_{x}$ with equivalence ratio have been analysed using diesel engine simulation models. These models can reduce the number of experiments. Computer simulation has contributed enormously towards new evaluation in the field of internal combustion engines. Mathematical tools have become very popular in recent years owing to the continuously increasing improvement in computational power.
\end{abstract}

Index terms: Emissions, Bio fuels, Simulation Models

\section{INTRODUCTION}

Diesel engine being most efficient engine today, plays an important role in transportation, agricultural sector and to meet many other basic human need. The petroleum fuels play a very important role in the development of industrial growth. As the fossil fuel resources are depleting day by day because of their lavish consumption; hence it is imperative to find an alternative environment friendly fuel. We all are well aware that the emission from diesel engines has been a great source of concern from an environmental point of view, especially oxides of nitrogen (NOX), smoke and particulates. Table1.shows the continuous reduction in emissions standards set for Diesel engines.. Biodiesel is one of the best available sources to fulfil the energy demand of the world. India is importing more than $80 \%$ of its fuel demand and spending a huge amount of foreign currency on petroleum fuels as India accounts only $0.7 \%$ ( 9.0 billion barrels) share of global proven oil reserves. Biodiesel is gaining more and more importance as an attractive fuel due to the depleting nature of fossil fuel resources.

\subsection{Alternative Fuels Technologies:}

The use of alternative fuels technologies can provide significant reductions in NOx and PM emissions, especially in Diesel engines for on-road, and off-road applications. The introduction of alternative fuels for internal combustion engines is likely to occur at an increasing rate.There are some following reasons to adopt other type of renewable fuels which can be used in vehicle.

(i) Decrease the dependency on import petroleum product.

(ii) Utilization of agricultural surpluses.

(iii) Use of renewable energy.

(iv) Environmental benefits.

(v) Public health.

Table1:Emission standards in recent years.

\begin{tabular}{|l|l|l|l|l|}
\hline $\begin{array}{l}\text { Capacity of } \\
\text { Diesel } \\
\text { engine }\end{array}$ & $\begin{array}{l}\text { Date of } \\
\text { implementat } \\
\text { ion }\end{array}$ & $\begin{array}{l}\text { Emission Limits } \\
\text { (g/kW-hr) }\end{array}$ \\
\cline { 3 - 6 } & & $\mathrm{NO}_{\mathrm{x}}$ & $\mathrm{HC}$ & $\mathrm{CO}$ \\
\hline $\begin{array}{l}\mathrm{Up} \text { to } 19 \\
\mathrm{~kW}\end{array}$ & $1-7-2005$ & 9.2 & 1.3 & 3.5 \\
\hline $\begin{array}{l}\mathrm{Up} \text { to } 19 \\
\mathrm{~kW}\end{array}$ & $1-1-2004$ & 9.2 & 1.3 & 5.0 \\
\hline
\end{tabular}

\subsection{Bio Diesel:}

Bio diesel is nothing but mono alkyl ester of long chain fatty acids mainly derived from vegetable oils or animal fats. Bio diesel can be blended at any ratio with petroleum diesel to create a bio diesel blend. It can be used in compression ignition engines with little or no modifications in filter and injector. Bio diesel is biodegradable, nontoxic and essentially 
free of sulphur and aromatics. Bio diesel offers safety benefits over petroleum diesel because it is much less combustible, with a flash point greater comparedto petroleum diesel. Biodiesel is a cleaner burning diesel replacement fuel made from natural, renewable sources such as new and used vegetable oils and animal fats. The low level blends (20\% and less biodiesel with diesel) generally do not require any engine modification. Use of bio diesel in a conventional diesel engine substantially reduces emissions ofcarbon mono oxide, sulphates, unburned hydrocarbons, poly cyclic aromatics hydrocarbons and particulate matter. Common feed stocks for bio diesel are soy bean oil, palm oil, jatropha oil,mahuaoil,neem oil , sunflower oil, rapeseed oil and linseed oil etc.

\section{LITERATURE REVIEW}

For the past few years biodiesel as an alternate fuel has been extensively studied by numbers of researchers and scientists and developed different methods for biodiesel production from various bio fuels. A brief review of these methods has presented here.

Monyemet al.,[5]found that the oxidation can affect some chemical and physical properties of biodiesel during storage. One drawback of biodiesel is that it is more prone to oxidation than petroleum-based fuels and in its advanced stages, can cause acidity in the fuel and form insoluble gums and sediments that can plug fuel filters.

Hossainet.al.,[11] studied effect of different types of alcohol on the percentage yield of biodiesel. Methanol, ethanol and butanol were used in this experiment. The reactions were carried out by using $0.5 \% \mathrm{NaOH}, 1: 1$ oil to alcohol molar ratio for $2 \mathrm{~h}$ at room temperature. The results show that methanol gave the best yield, followed by ethanol and butanol. For methanol, the yield of biodiesel achieved was $71.2 \%$. Methanol is used widely because it is relatively cheaper than other alcohols and has chemical and physical advantages over other alcohols.

\subsection{Methods for Bio Diesel production}

2.1.1. Pyrolysis:MinodoraLecaet.al.[12], Pyrolysis or catalytic cracking reduces the viscosity of vegetable oils and increasescetane number. The products contain alkanes, alkenes and carboxylic acids and have permissible amounts of sulphur, water and particulate matter. The method requires expensive equipment and needs to separate the products by distillation, which is energy consuming. Moreover, the products are similar to petrol containing sulphur that makes them less ecofriendly and are not accepted from the points of view of, carbon residues, ash content and pouring point

2.1.2. Micro Emulsification:MinodoraLecaet.al. [12], Micro emulsification, alsoincrease the cetane number and reduce the viscosity. Diesel fuel, vegetable oil, alcohol, surfactant and additive for increasing of cetane number are mixed and the mixture transformed, under stirring into a micro emulsion with lowers viscosity. Alcohols as methanol, ethanol and propanol are used as additives for reducing of viscosity, higher ones as surfactants and alkyl nitrates as cetane number improvers. But biodiesel micro emulsions produce injector needle sticking and formation of carbon deposits due to the incomplete combustion if they are used for a long time.

2.1.3. Transesterification:The main drawback of vegetable oil is their high viscosity and low volatility, which causes poor combustion in diesel engines .The purpose of transesterification process is to reduce the viscosity of the oil.. The transesterification is the process of removing the glycerides and combining oil esters of vegetable oil with alcohol. This process reduces the viscosity to a value comparable to that of diesel and hence improves combustion. Apart from these methods transesterification is better than first two as it shows properties close to diesel.

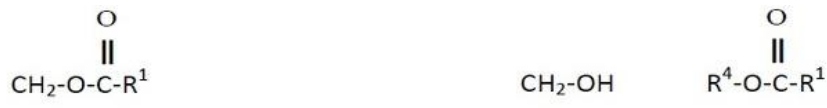

$$
\begin{aligned}
& \mid \begin{array}{lll}
0 & \\
\text { II } & \text { Catalyst }
\end{array} \\
& \mathrm{CH}-\mathrm{O}-\mathrm{C}-\mathrm{R}^{2}+3 \mathrm{R}^{4} \mathrm{OH} \stackrel{\text { 列 }}{\longleftarrow} \mathrm{CH}_{2}-\mathrm{OH}+\mathrm{R}^{4}-\mathrm{O}-\mathrm{C}-\mathrm{R}^{2}
\end{aligned}
$$

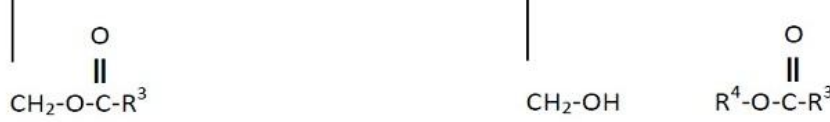

$$
\begin{aligned}
& \text { (Triglyceride esters) Alcohol Glycerol Esters } \\
& \text { Vegetable oil } \\
& \text { Triglyceride }+3 \text { Monohydric alcohol } \longleftrightarrow \text { Glycerol + Esters }
\end{aligned}
$$

Figure 1: Structure of triglycerides and principle of the transesterification reaction

\subsection{Effectof Bio Diesel on Combustion and Emission}

\section{ofDiesel Engines:}

YuZhang et al [1] investigated the use of blends of methyl esters of soybean oil and diesel in a turbo-charged, fourcylinder, direct injection diesel engine modified with bowl in piston and medium swirl type. They found that the blends gave a shorter ignition delay and similar combustion characteristics as diesel. The results of emission concentration in flame show that total hydrocarbon (THC) emissions of biodiesel blends are significantly lower than that of conventional diesel..

Altinet. al.[3] tested single cylinder direct injection diesel engine with the use of methyl esters of sunflower oil, cottonseed oil, soybean oil and corn oil as fuel. They reported that thermal efficiency did not change and fuel consumption 
increased compared to diesel. The emissions like $\mathrm{CO}$ and $\mathrm{HC}$ were reduced by $15 \%$ and $16 \%$ compared to diesel fuel results.

Schumacher et. al [6] investigated that fuelling with biodiesel/diesel fuel blends effectively reduced particulate matter, unburned hydrocarbons, and carbon monoxide while increasing oxides of nitrogen emissions. The optimum blend of biodiesel and diesel fuel, based on the trade-off of PM decrease and NOx increase, was a B-20 fuel blend. Increased NOx emissions can be reduced by retarding engine timing while subsequently maintaining emission reductions associated with fuelling a diesel engine with a B-20 fuel blend.

Ali et al. [7] studied the use of different blends of soyabean methyl ester and ethanol with diesel as fuel in a Cummins 522 $\mathrm{kW}$, six-cylinder, turbo-charged, direct injection. The tests showed reduction in carbon monoxide emissions and no change in carbon dioxide and hydrocarbon emissions. The NOX and smoke emissions were on par with diesel.

Scholl and Sorenson et.al[8] found that carbon monoxide, oxides of nitrogen (NOX) and smoke emissions were slightly lower for soybean ester than diesel, whereas $\mathrm{HC}$ emission showed 50\% reduction compared to diesel.

Pryor, et al. [10] conducted short and long-term engine tests using neat soybean oil in a small diesel engine. Short-term tests with soybean oil indicated the performance similar to that of diesel and long-term testing could not be carried out due to power loss and carbon build-up on the injectors. They concluded that the soybean oil can be considered for shortterm operation only.

Table2:Components of soybean oil and diesel:

\begin{tabular}{|l|l|l|}
\hline Fuel & Diesel & Soybean oil \\
\hline Fattyacid analysis & Notation & $\%$ \\
\hline Palmitic & $16: 0$ & 10.80 \\
\hline Estearic & $18: 0$ & 3.00 \\
\hline Oleic & $18: 1$ & 26.50 \\
\hline Linoleic & $18: 2$ & 47.30 \\
\hline Linolenic & $18: 3$ & 9.00 \\
\hline econsenoic & $20: 1$ & 1.40 \\
\hline Other traces & - & 0.90 \\
\hline
\end{tabular}

Table3:Comparison of properties of diesel, soybean oil and soybean ethyl ester:

\begin{tabular}{|l|l|l|l|}
\hline Property /Fuel & Diesel & Soybean oil & $\begin{array}{l}\text { Ethyl } \\
\text { ester }\end{array}$ \\
\hline Viscosity at $38^{0} \mathrm{C}$ & 2.94 & 35.36 & 5.03 \\
\hline $\begin{array}{l}\text { Specific gravity at } \\
15^{0} \mathrm{C}\end{array}$ & 0.8162 & 0.9296 & 0.8330 \\
\hline $\begin{array}{l}\text { Heat of combustion } \\
\text { MJ/kg }\end{array}$ & 42.51 & 37.16 & 40.16 \\
\hline Cloud point ${ }^{\circ} \mathrm{C}$ & 7 & -9 & 15 \\
\hline Pour point ${ }^{\circ} \mathrm{C}$ & -8 & -12 & 5 \\
\hline Flash point ${ }^{0} \mathrm{C}$ & 53 & 284 & 55 \\
\hline Fire point ${ }^{0} \mathrm{C}$ & 59 & 290 & 60 \\
\hline $\begin{array}{l}\text { Ash content } \\
\%(w / W)\end{array}$ & 0.0005 & 0.17 & 0.0049 \\
\hline $\begin{array}{l}\text { Carbon } \\
\text { residue\%(w/W) }\end{array}$ & 0.17 & 7.25 & 0.48 \\
\hline Acid value(w/w) & 0.22 & 0.53 & 0.28 \\
\hline Free glycerine & - & - & 0.015 \\
\hline Total glycerine & - & - & 0.210 \\
\hline
\end{tabular}

\section{MODELLING OF NOX FORMATION:}

Whilenitric oxide (NO) and nitrogen dioxide (NO2), are grouped together as NOx emissions. NO is predominant in diesel engine. Therefore, only NO formation is considered and in simulation model all calculation are carried out with thermal mechanism.

NO formation is modelled using the Zedovich Mechanism. The amounts of NO formation for each thermodynamic cycle can be predicted. After establishing the temperature and pressure data at each crank angle using Zero dimensional model the equilibrium concentrations of the nitrogen and oxygen can be predicted, which is used for better prediction of NO formation.

The oxidizing of nitrogen is on the chain mechanism, basic reactions are:

$$
\begin{aligned}
& \mathrm{O}_{2} \longleftrightarrow 2 \mathrm{O} \\
& N_{2}+O \stackrel{K_{1 f}}{\longleftrightarrow} \mathrm{NO}+N
\end{aligned}
$$




$$
\begin{gathered}
N+O_{2} \stackrel{K_{2 f}}{\longrightarrow} N O+O \\
\frac{d[N O]}{d t}=2 * K_{1 f}\left[\frac{K_{p} P^{0}}{R u * T}\right]^{1 / 2}\left[N_{2}\right]\left[O_{2}\right]^{1 / 2} \\
\frac{d[N O]}{d \theta}=\frac{2}{\omega} * K_{1 f}\left[\frac{K_{p} P^{0}}{R u^{*} T}\right]^{1 / 2}\left[N_{2}\right]\left[O_{2}\right]^{1 / 2} \\
K_{1 f}=1.82 * 10^{11 *} e^{\left[\frac{-38370}{T}\right]} \\
K_{p}=e^{\left(\frac{-\Delta G_{T}^{0} T}{R u T}\right)} \\
{\left[O_{2}\right]=0.21 \frac{P}{R u T}} \\
\Delta G_{T}^{0}=\left[2 * g_{f, O}^{0}-g_{f, O_{2}}^{0}\right]_{T} \\
{\left[N_{2}\right]=0.79 \frac{P}{R u T}}
\end{gathered}
$$

Where

$\left[\mathrm{O}_{2}\right]_{=\text {Equilibrium oxygen concentration in moles }}$ $\left[\mathrm{N}_{2}\right]_{=\text {Equilibrium Nitrogen concentration in moles }}$

\section{ANALYSIS \\ OF \\ EMISSION}

\section{CHARACTERISTICS:}

\subsection{Carbon dioxide:}

From the fig 2 it can be observed as soon as equivalence ratio increase the $\mathrm{CO} 2$ value also increase because combustion proceeds to completion, oxidation of $\mathrm{CO}$ to $\mathrm{CO} 2$ occurs through recombination reactions between $\mathrm{CO}$ and various oxidants. For equivalence ratio higher than 1 amount of air is reduced and is not sufficient amount for the formation of $\mathrm{CO} 2$, so amount of $\mathrm{CO} 2$ is decreased.

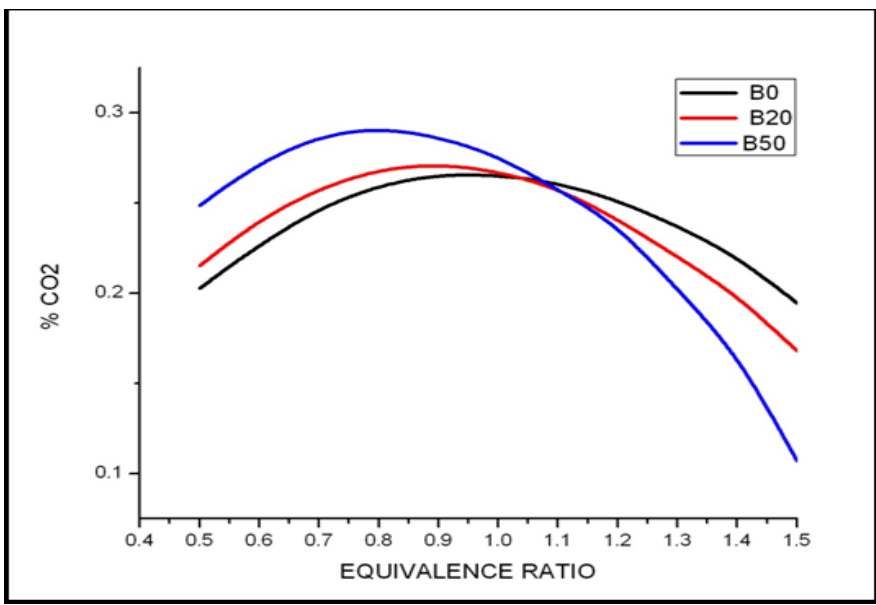

Figure 2: Variation of percentage of $\mathrm{CO} 2$ with equivalence ratio

\subsection{Carbon mono oxide:}

Carbon monoxide $(\mathrm{CO})$ is an intermediate product in the combustion of hydrocarbons .It is formed mainly due to incomplete combustion, which is affected by lack of oxidants, temperature, and residence time. Combustion of fuel-rich mixtures usually produces high $\mathrm{CO}$ emissions, but since diesel combustion is lean and has an abundant amount of air, CO from diesel combustion is extremely low. However, the main parameter affecting its formation remains a low $\mathrm{A} / \mathrm{F}$ ratio. Before equivalence ratio 1 within the engine enough air is present so all carbon is converted into carbon di oxide but after equivalence ratio 1 there is lack of air so carbon is converted into carbon mono oxide. The concentration of $\mathrm{CO}$ always higher in case of Diesel as compared to bio fuel and as the percentage of bio fuel increases in Blend the amount of $\mathrm{CO}$ emission decreases because bio diesels have oxygen in its chemical structure.

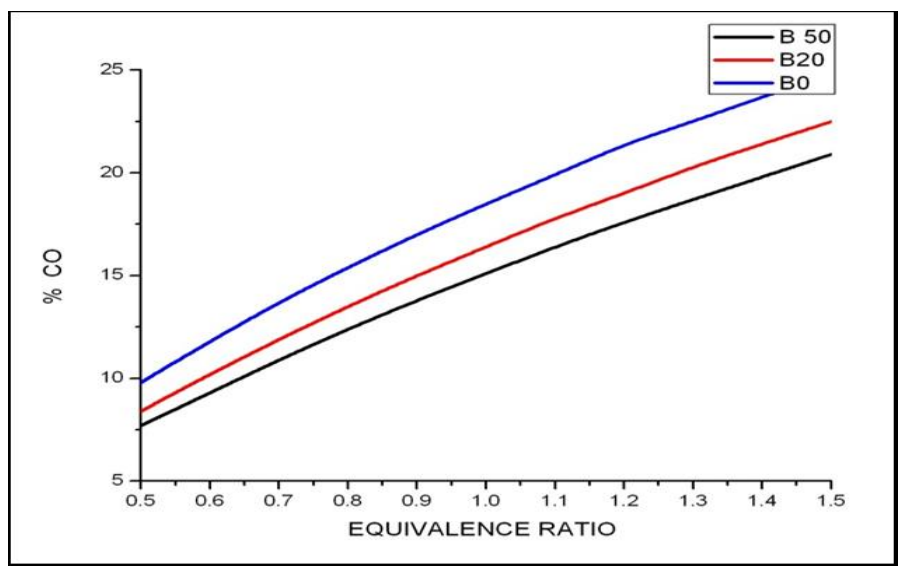

Figure 3: Variation of percentage of $\mathrm{CO}$ with equivalence ratio 


\subsection{Nitrous oxide:}

NO formation is highly dependent on the combustion temperature and the amount of oxygen present in the engine. For equivalence ratio less than 1 within the engine enough amount of air is present so some nitrogen reacts with oxygen and converted into NO. But after equivalence ratio 1 there is lack of air so value of NO decreases. Combustion temperature of Diesel is more than biodiesel so quantity of exhaust NO is more than from biodiesel.

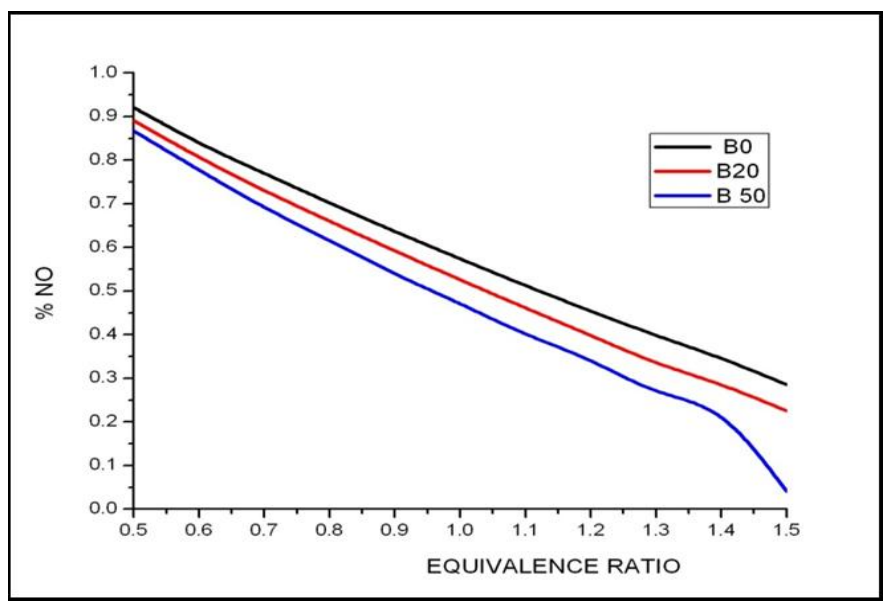

Figure 4: Variation of percentage of NO with equivalence ratio

\subsection{Water vapours}

When mixture of fuel and air is lean water vapour formation is negligible due to cooling effect of air but when equivalence ratio is increased the Water vapour formation increases and become maximum at equivalence ratio 1 since at this temperature temperature is maximum and after this it starts decreasing since dissociation effect dominates

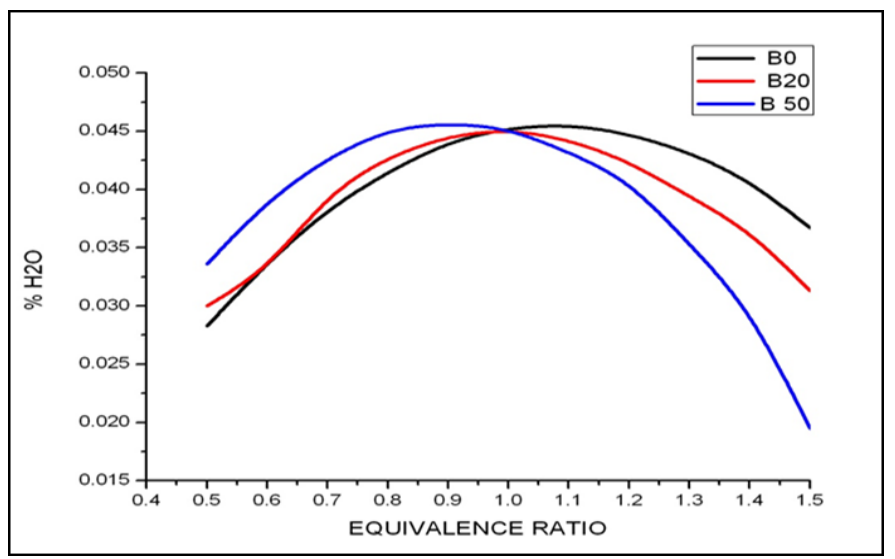

Figure 5: Variation of percentage of $\mathrm{CO}$ with equivalence ratio

\subsection{Other product:}

Before equivalence ratio 1 within the engine enough air is present so Oxygen presents in exhaust gas in enough quantity. Before equivalence ratio 1 within the engine enough air is present so all fuel is burn so there is not formation of hydrogen But after equivalence ratio 1 there is lack of air so all fuel is not burn so hydrogen go out with exhaust air.

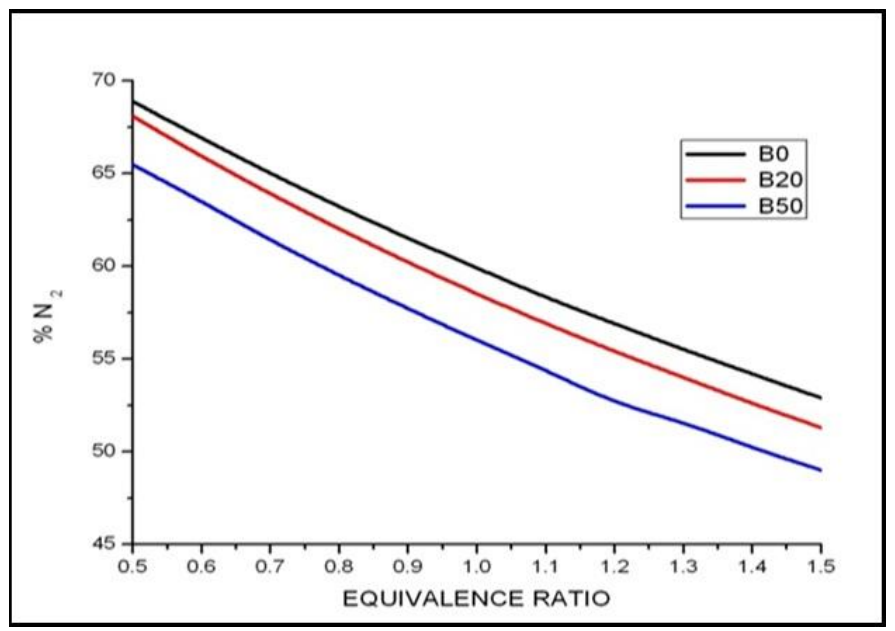

Figure 6: Variation of percentage of $\mathrm{N} 2$ with equivalence ratio

\section{CONCLUSION}

In the present work it was observed that the emissions for B50 and B20 were lower than that for pure diesel. However the literature provides information that bio diesel combustion results in higher NOx emissions. The present model calculates the NO formation based on temperature, practically biodiesel combustion results in higher NO emissions due to effects like higher bulk modulus, higher fuel consumptions due to higher densities.

\section{REFERENCES}

[1]. Yu Zhang, and Jon H. Van Gerpen., "Combustion Analysis of Esters of Soybean Oil in a Diesel Engine". SAE paper 960765,2007 .

[2]. Tsolakis A, Megaritis A., "Exhaust gas assisted reforming of soy bean methyl ester for reduced exhaust emissions of CI engines". Biomass and Bioenergy ,2005;29:483-605.

[3]AltınRecep, C,etinkayaSelim, Yücesu $\mathrm{Hu}$ “ seyinSerdar. "The potential of using vegetable oil fuels as fuel for diesel engines". Energy Conversion and Manage- ment 2001; 42:529-38.

[4]. Haas MJ, Scott KM, Alleman TL, Mccormick RL, "Engine performance of biodiesel fuel prepared from soybean soapstock: a high quality renewable fuel produced from a waste feedstock.” Energy Fuels, 15: 207-1212, 2001. 
[5]Monyem A, Van-gerpen JH, "The effect of biodiesel oxidation on engine performance and emissions". Biomass and Bioenergy, 20: 317-325,2001.

[6] Schumacher LG, Borgelt SC, Fosseen D, Goetz W, Hires WG. "Heavy-duty engine exhaust emission tests using methyl ester soybean oil/diesel fuel blends". Bioresource Technology 1996; 57:31-6.

[7] Ali Yusuf, Hanna Milford A, Borg Joseph E., "Optimization of diesel, Soy bean methyl ester and ethanol blend for reducing emissions from diesel engine". Bioresource Technology 1995;52:237-43.

[8] Scholl KW, Sorenson SC., "Combustion of soybean oil methyl ester in a direct injection diesel engine". SAE paper 930934, 1993.

[9]. Schumacher, L. G., Borgelt, S. C., and Hires, W. G., "Soydiesel/Biodiesel Blend Research". ASAE paper No. 936523. ASAE, St. Joseph, MI.1993.

[10]. Pryor RW, Hanna MA, Schinstock, BashfordLL., "Soybean oil fuel in a small diesel engine". Transactions of the ASAE 1983;26:333-7.

[11]. Hossain A. B. M. S., Nasrulhaq Boyce A., "Salleh A. and Chandran S., Biodiesel production from waste soybean oil biomass as renewable energy and environmental recycled process",African Journal of Biotechnology Vol. 9(27), pp. 4233-4240, 5 July, 2010.

[12]. MinodoraLeca, LuminiţaTcacenco,Marin Micutz1, TeodoraStaicu,'Optimization of biodiesel production by transesterification of vegetable oils using lipases",Vol. 15, No.5, 2010

[13]. Jagdish D., Kumar R., Zero Dimensional Simulation Of Combustion Process Of A DI Diesel Engine Fulled With Biofuels, World Academy Of Science, Engineering And Technology 802011 pp 819-825 